\title{
Perioperative screening, management, and surveillance of Barrett's esophagus in bariatric surgical patients
}

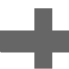

Geraldine $\mathrm{OOi}^{1}$, Alison Browning ${ }^{2}$, Michael W Hii, ${ }^{2,3}$ and Matthew Read ${ }^{2,3}$

${ }^{1}$ Department of Surgery, Central Clinical School, Monash University, Prahran, Australia

${ }^{2}$ Department of Upper GI and Hepatobiliary Surgery, St. Vincent's Hospital, Fitzroy, Australia

${ }^{3}$ Department of Surgery, the University of Melbourne, St. Vincent's Hospital, Fitzroy, Australia

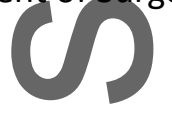

Address for correspondence: Geraldine Ooi, Department of Surgery, Central Clinical School, Monash University, Level 6, 99 Commercial Road, Prahran, Victoria 3181, Australia.

geraldineooi@gmail.com

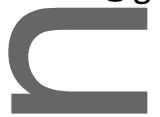

Short title: Barrett's Esophagus and Bariatric Surgery

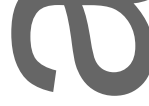

Abstract

Obesity is a strong risk factor for Barrett's esophagus (BE), the only proven precursor lesion to EAC. Bariatric surgery is currently the only reliable treatment that achieves of long-term sustained weight loss, however, it can markedly affect the development of de novo $\mathrm{BE}$, and the progression or regression of existing $B E$. Bariatric procedures may also have implications on future surgical management of any consequent EAC. In this review, we examine current evidence and published guidelines for $\mathrm{BE}$ in bariatric surgery. Current screening practices before bariatric surgery vary substantially, with conflicting recommendations from bariatric societies. If diagnosed, the presence of $\mathrm{BE}$ may alter the type of bariatric procedure. A selective screening approach prevents unnecessary endoscopy, however, there is poor symptom correlation with disease. Studies suggest that sleeve gastrectomy predisposes patients to gastroesophageal reflux and de novo BE. Conversely, Roux-en-Y gastric bypass is associated with decreased reflux and potential improvement or resolution of $\mathrm{BE}$. There are currently no guidelines addressing surveillance for BE following bariatric surgery.

This is the 1 , r manuscript accepted for publication and has undergone full peer review but has not been through the copyediting, typesetting, pagination and proofreading process, which may lead to differences between this version and the Version of Record. Please cite this article as doi: $\underline{10.1111 / \text { nyas. } 14441 .}$.

This article is protected by copyright. All rights reserved. 
$\mathrm{BE}$ is an important consideration in the management of bariatric surgical patients. Evidence-based recommendations are required to guide procedure selection and postoperative surveillance.

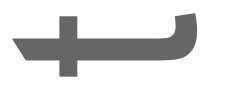

Keywords: Barrett's esophagus; bariatric surgery; endoscopy; esophagus; stomach

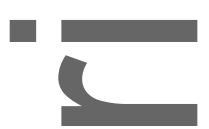

Introduction

Worldwide rates of obesity have tripled over the last few decades, with over $13 \%$ of the adult population now classified as obese (body mass index (BMI) over $30 \mathrm{~kg} / \mathrm{m}^{2}$ ). ${ }^{1}$ Bariatric surgery is currently the only reliable means of achieving substantial and sustained weight loss accompanied by remission and reduced incidence of metabolic comorbidities in morbidly obese individuals ${ }^{2,3}$.

Esophagea! pathology is relatively common in obesity, ${ }^{4,5}$ and potentially exacerbated by bariatric surgical procedures. This includes Barrett's esophagus (BE), the only known precursor lesion of esophageal adenocarcinoma (EAC). There are multiple mechanisms, both mechanical and metabolic, for this association in obesity. The incidence of EAC in Western society has increased up to five-fold in the last few decades, ${ }^{6}$ closely mirroring the rising rates of obesity.

It is important to recognize BE in the bariatric surgical population. Preoperative endoscopy may be an opportune time to screen an already at-risk population, and its detection can suggest a change of surgical strategy.-Second, bariatric surgical procedures can impact gastroesophageal reflux (GER) and, therefore, theoretically affect the development of de novo $\mathrm{BE}$, or progression and regression of existing BE. Finally, bariatric surgery can significantly impact future curative treatments for esophageal adenocarcinoma (EC) that may develop from BE.

In this review, we discuss the link between BE, obesity, and bariatric surgery, and review the evidence around perioperative screening and surveillance.

$B E$ and obesity

$\mathrm{BE}$ is a premalignant condition characterized by the conversion of the normal esophageal squamous epithelium to the metaplastic columnar epithelium containing goblet cells. ${ }^{7}$ This is thought to be in response to prolonged exposure to acid reflux. BE can progress from metaplasia to dysplasia, and subsequently EAC.

Central adiposity and high BMI are risk factors for BE. A meta-analysis by Singh et al. showed a significant increase in odds of $\mathrm{BE}$ with central adiposity ( $\mathrm{OR}=1.98 ; 95 \% \mathrm{Cl}: 1.52-2.57)$, with a strong dose-response relationship. ${ }^{8}$ This association remains significant after controlling for gastroesophageal reflux disease (GERD). Higher BMI is also significantly correlated with increased length of $\mathrm{BE}(r=0.25, P<0.0001)$ and greater rates of long-segment $\mathrm{BE} .^{9}$

This article is protected by copyright. All rights reserved. 
Various mechanisms have been implicated in the development of BE in obesity. These can be divided into mechanical, metabolic, and dietary factors. ${ }^{5}$

Mechanically, obesity increases intragastric pressures and disrupts the antireflux mechanisms, both of which encourage acid reflux into the esophagus. High BMI and waist circumference are independently associated with dysfunction of the GE function, including separation of the diaphragmatic hiatus and increased frequency of lower esophageal sphincter relaxation, ${ }^{10,11}$ allowing passage of the refluxate into the esophagus. Intragastric pressures from visceral abdominal fat further exacerbate acid reflux. ${ }^{12}$

Metabolic factors are also important mechanisms in the development of BE and neoplasia. Overexpansion of adipose tissue in obesity produces a state of low-grade systemic inflammation, owing to changes in immune profile to a proinflammatory state and over-expression of inflammatory cytokines, such as tumor necrosis factor- $\alpha$, interleukin (IL)-1 $\beta$, and IL- 6 . ${ }^{13}$ The paracrine and endocrine profile of adipose tissue changes with increased leptin and decreased adiponectin. Increasing lipolysis results in the release of saturated free fatty acids, and excess adiposity results in ectopic fat storage in depots, such as the liver, pancreas, and muscle, leading to organ dysfunction and insulin resistance. ${ }^{14}$ These changes in leptin, adiponectin, insulin resistance, and systemic inflammation have all been linked to the development and progression of BE. ${ }^{5}$

Various dietary factors have been associated with the development of $\mathrm{BE}$, many of which are associated with obesity. Meta-analyses show that low dietary fiber intake is associated with an increased risk of $B E$ and $E A C^{15}$. Composition of dietary fats, towards high animal fat intake, has been shown to change bile acid composition and increase rates of metaplasia, dysplasia, and adenocarcinoma $(A C)$ in animal models ${ }^{16}$. Alternatively, a high intake of beta-carotene (for example, from carrots, dark leafy greens, and cantaloupe) is protective from dysplastic $B E^{17}$.

Bariatric surgery and reflux disease

GERD refers to pathological, retrograde passage of gastric and/or biliopancreatic contents into the esophagus, such that symptoms or pathology occurs. ${ }^{18}$ In the general population, it is one of the most common diaghoses during endoscopy, with a prevalence of between 10 and $20 \%$. This prevalence increases with obesity and may be up to $60 \% .{ }^{19}$

Trends in bariatric surgery have changed dramatically over the last 10-20 years. In this time, sleeve gastrectomy (SG) has increased from $3.0 \%$ in 2008 to $54 \%$ of all cases performed in the United States in 2014. Laparoscopic adjustable gastric banding (LAGB) has fallen from $29 \%$ to $1 \%$ of bariatric cases, and Roux-en-Y gastric bypass (RYGB) decreased from $52 \%$ to $32 \% .{ }^{20}$ Randomized control trials have shown similar weight loss outcomes for SG and RYGB. ${ }^{21,22}$ These trends are likely due to a combination of reasons, such as procedural complexity, insurance coverage, complication profile, and surgeon/patient preferences.

Bariatric surgery can have profound effects on the mechanisms promoting or alleviating GERD. RYGB is a popular choice for obese patients with significant reflux, with studies consistently showing symptomatic relief, reduction in acid suppressor medication, improvement in acid exposure, and

This article is protected by copyright. All rights reserved. 
esophagitis. ${ }^{23}$ Mechanistically, RYGB creates a small low-pressure gastric pouch with few acidproducing parietal cells and a long Roux limb that prevents reflux of duodenal contents into the esophagus. Prevention of bile reflux is important, given the link between $B E$ and the exposure of the esophageal mucosa to the biliopancreatic fluid. ${ }^{24}$ Studies on LAGB have conflicting results, with both symptomatic relief and reduction in medication, as well as studies reporting exacerbation of reflux. ${ }^{23}$ The majority of studies that have assessed reflux after SG report an increase in GERD symptoms and objective evidence of acid reflux, such as erosive esophagitis. ${ }^{25}$ Proposed mechanisms that exacerbate reflux include an increase in intragastric pressures, intrathoracic sleeve migration, fundal dilatation, delayed gastric emptying, and esophageal motility disorders. ${ }^{23}$ However, there are some studies that have shown the opposite, with improvement in GERD and the esophagitis. ${ }^{26-28}$ This could be due to faster gastric emptying, alterations in the gastrointestinal (GI) hormonal milieu, decreased acid secretion, and postoperative weight loss. Technical factors, such as concomitant hiatus hernia repaiy, may also contribute to differences between studies.

With the link between obesity, BE and EAC well established, diagnosing BE in bariatric surgical patients is important. Understanding the effect of bariatric procedures on $B E$ is vital for tailoring surgery to individuals and counseling patients on the risk. The presence of $\mathrm{BE}$ in patients undergoing bariatric surgery is particularly important, as bariatric procedures can significantly influence surgical options for curative management of EAC.

The primary aim of this review was to summarize the current evidence on:

1. Screening for BE before bariatric surgery;

2. The effects of bariatric surgery on BE;

3. Surveillance for patients who have/develop BE following bariatric surgery.

\section{Literature search}

We performed a comprehensive literature search to identify studies reporting any experiences or outcomes with BE and bariatric surgery. We searched MEDLINE, PubMed, and the Cochrane Library (until January 2020). The search items used were derivatives of BE and bariatric surgery. Original research, clinical trials, review articles, and meta-analyses were all included.

\section{Screening for BE before bariatric surgery}

The role of routine endoscopy before bariatric surgery remains controversial. There is a wide variety of practices, with many centers performing routine endoscopy while others practice selective endoscopy, often based on symptoms. ${ }^{29}$ This is reflected by varying recommendations among surgical societies (Table 1). The European Association for Endoscopic Surgery (EAES) recommends routine upper $\mathrm{GI}(\mathrm{UGI})$ endoscopy or upper $\mathrm{GI}$ series for all bariatric patients. ${ }^{30}$ By contrast, the American Society for Metabolic and Bariatric Surgery (ASMBS) and the American Society for Gastrointestinal Endoscopy (ASGE) both suggest an individualized approach, with investigations performed for those with clinically significant symptoms. ${ }^{31,32}$ The evidence underlying these recommendations are somewhat weak.

This article is protected by copyright. All rights reserved. 
Advocates of selective endoscopy argue that clinically important findings are not common in the bariatric population, and therefore endoscopy can be offered based on the symptoms and the risk. Current reports suggest that the proportion of patients where endoscopy alters surgical approach or has a clinical impact varies from $<1 \%$ to $24.6 \%$ of patients. ${ }^{33-37}$ There is significant heterogeneity between studies around the definition of "clinically significant" impact, with some defining this as change or delay in surgery, while others include the change in medical management as significant.

Many studies have reported a lack of correlation between symptoms and detection of BE (Table 2)..$^{36,38-41}$ Up to $60 \%$ of patients diagnosed with BE on preoperative endoscopy are asymptomatic. Saarinen et al..$^{36}$ examined the endoscopy results of 1275 bariatric patients, and reported a rate of BE of 3.7\% ( $n=47)$, of whom $28(59.6 \%)$ were asymptomatic. Similarly, D'Silva et al. ${ }^{41}$ studied 675 preoperative endoscopies and found that $60 \%$ of those findings consistent with GERD, including BE and reflux esophragitis, were asymptomatic. The lack of symptoms together with the lack of accurate noninvasive testsis likely to decrease the efficacy of a selective approach to endoscopy before bariatric surgery.

Endoscopy has the advantage of detecting mucosal lesions, such as BE or early AC, which are often imperceptible or too subtle to be diagnosed by other means. In individual studies, BE was found in $<1 \%$ to $15 \%$ of preoperative endoscopy (Table 2). ${ }^{36,37,39-48}$ Two systematic reviews and meta-analyses have examined the utility of preoperative endoscopy. ${ }^{38,49}$ Parikh et al. reported an overall incidence of BE of $1 \%$ ( 45 of 4511 patients), with EAC found in $0.9 \%$ ( 4 of 4511 ). Bennett et al. combined the findings of 19 studies with 5802 patients, finding an incidence of BE of $2.1 \%$ and esophageal cancer in $0.2 \%$. Data on how many patients were symptomatic is lacking, as only two studies in the metaanalysis made the distinction between those with and without symptoms. Both these systematic reviews have advocated for selective endoscopy based on relatively low numbers.

Given the number of bariatric operations performed annually worldwide, and the implications for BE screening and early cancer detection, over $2 \%$ of bariatric patients with BE is a clinically significant number. The clinical significance is further increased given that majority of bariatric patients are relatively young, which leads to an increased lifelong risk of cancer.

Additionally, bariatric surgery has implications for curative surgical procedures and conduit reconstruction. Resectional procedures, such as SG or resectional RYGB, eliminate the use of the stomach as a future reconstructive option during esophageal resection procedures. Reconstruction with other conduits, such as colon or small bowel, are technically more demanding and have an increased risk. ${ }^{50}$ Additionally, any gastric procedure may cause scarring or stricturing, increasing the chance of complications if future surgery is required. ${ }^{51}$ In this regard, excluding preexisting BE is vital before committing to bariatric surgery.

\section{Effect of bariatric surgery on BE}

SG

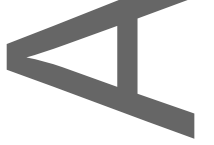

Current published literature studying BE in SG patients strongly suggests an increased rate of de novo BE after SG. A recent systematic review by Yeung et al. (2020) reported on the impact of SG on 
reflux-related measures, including symptomatic reflux, erosive esophagitis, and $\mathrm{BE}^{25}$ (Table 3). Five studies examined the incidence of BE after SG. Over a follow-up period of 24 months or more, the rate of de novo $\mathrm{BE}$ was $8 \%(95 \% \mathrm{Cl}: 4-13 \%, P<0.0001)$. This review showed significant increases in de novo reflux (rate of $20 \%$ ), erosive esophagitis (28\%), and PPI use (36\%). Furthermore, $4 \%$ of patients underwent conversion to RYGB for the treatment of severe reflux. All studies were retrospective or cohort studies with no randomized control trials, and there was a large amount of heterogeneity in all analyses.

Table 4 shows a summary of recent individual studies examining the incidence of BE after SG. Participant numbers range from 43 to 231 and a follow-up varied from 58 months to over 10 years. Rates of de novo BE ranged from $1.2 \%$ up to $18.8 \%$, with between 5 to 10 years of a follow-up.

Roux-en-Y gastric bypass

RYGB appears to be beneficial in the setting of BE. A systematic review by Adil et al. in 2019 reported on 117 patients with biopsy-proven preoperative $B E$ and endoscopic follow-up at over 1 year after RYGB surgery. Meta-analysis showed significant regression in BE after RYGB, with a risk difference of -0.56 (95\% Cl: -0.69 to $-0.43, P<0.001$ ). This corresponded to 64 participants $(54.7 \%)$ showing histological regression, with two (1.7\%) showing progression. This effect was seen in both short- and long-segment $\mathrm{BE}$ (risk difference of -0.51 and -0.46 , respectively, $P<0.001$ for both)..$^{52,53}$ Heterogeneity between studies was moderate, with some publication bias owing to a small study size (Table 3).

Results of individual studies are seen in Table 5. All studies report improvement in BE after RYGB. Felsenreich et al. studied 10 patients who underwent RYGB as a revisional procedure for SG after a diagnosis of BE. They reported $80 \%$ remission, and objective improvements in acid exposure $(36.8 \%$ to $2.8 \%$ after a 24-h acid exposure) and DeMeester score (100 to 16.3). Individual studies suggest better rates of resolution in short- versus long-segment $B E^{52,53}$. The effects of weight loss quantity on the resolution of $B E$ has not previously been studied, but evidence suggests that greater weight loss may contribute to the resolution of BE. ${ }^{9}$ These studies further support the role of RYGB as a combined bariatric and antireflux procedure.

Many have advocated for RYGB as a revision procedure for patients who experience significant GERD post-SG. Felsenreich et al. (2019) studied 10 patients who underwent RYGB after SG due to severe reflux and $B E{ }^{54}$ At a mean follow-up time of 33.4 months, they noted a significant decrease in acid exposure (36.8\% to 3.8\% 24-h acid exposure) and drop in DeMeester score (100 to 16.3).

Furthermore, BE resolved in eight patients, including in one patient with small areas of dysplasia on preoperative endoscopy.

Other procedures

Few studies have examined the effect of other bariatric procedures on BE. There is only one case report of $\mathrm{BE},{ }^{55}$ and reports within larger outcomes studies of $\mathrm{BE}$ observed ${ }^{56,57}$ after LAGB. Due to paucity in the literature, the specific incidence of $B E$ after gastric banding is not known.

This article is protected by copyright. All rights reserved. 
We could not find studies specifically addressing the incidence of BE after other procedures, including single anastomosis gastric bypass, single anastomosis duodenal bypass, or biliopancreatic diversion.

\section{Surveillance for de novo BE after bariatric surgery}

There are currently no society guidelines specifically addressing potential de novo BE and surveillance postbariatric surgery. Current guidelines focus on known risk factors for $\mathrm{BE}$, including chronic GERD, older age, male gender, central obesity, Caucasian race, and tobacco use. ${ }^{59}$

The Interdisciplinary European Guidelines on Metabolic and Bariatric Surgery encourage "regular lifelong qualified surveillance" for all patients after bariatric procedures, including clinical, metabolic, and nutritional assessment. In particular, persistent severe Gl symptoms should be followed up with endoscopy and/or CT as a first diagnostic option. ${ }^{60}$ Similarly, the American Society of Gastrointestinal Endoscopy (ASGE) recommends endoscopy as the first-line diagnostic study for bariatric patients with abdominal pain, nausea, or vomiting. ${ }^{32}$ These recommendations prevent unnecessary delay in the diagnosis of significant pathology due to erroneously attributing them to a normal postoperative course after a bariatric procedure. The emphasis on symptoms, however, is likely to miss most cases of $\mathrm{BE}$. No routine endoscopic follow-up schedule has been recommended by any society.

There is no consensus on screening and surveillance for BE in the general population, and little evidence to support its use. Most societies have used a cut-off prevalence of BE of $10 \%$ to recommend screening ${ }^{61,62}$. Several risk factors have been identified, including the history of GERD, male gender, white race, age $>50$ years, smoking, obesity, and family history. The American Society of Gastrointestinal Endoscopy (ASGE) recognizes high-, moderate-, and low-risk groups. High-risk populations include those with a family history of EAC or BE, where screening is recommended. The moderate-risk group includes patients with GERD and another additional risk factor, including age $>50$, obesity/central adiposity, history of smoking, or male gender. The screening was not recommended for low-risk populations. When applied to the bariatric population, those with symptoms of GERD-will be of "moderate-risk" and, therefore, warrant screening and surveillance.

One concerning feature of acid reflux and BE after SG is the lack of correlation between endoscopic findings and reported symptoms. ${ }^{25,63,64}$ Soricelli et al. studied the association between symptoms of GER and endoscopic esophageal lesions after SG in 249 patients over a mean follow-up of 66 months ${ }^{64}$ They found no significant correlation between the symptoms of GERD and the severity of esophagitis or the presence of BE. In a study on GERD after SG, Genco et al. reported highest symptomatic reflux scores for Grade A and B esophagitis (visual analogue scale (VAS) of 3.1-3.4), lower reflux scores for Grade $C$ and D esophagitis (VAS $=2.4-2.8$ ), and the lowest reflux scores in patients found to have BE (VAS $=1.3) .{ }^{63}$ These studies highlight the difficulties in triaging patients with post-SG for selective gastroscopy.

Given current evidence suggesting the development of reflux and de novo BE in sleeve patients, it may be prudent to advocate for surveillance of patients 5-10 years after SG, or sooner if they are symptomatic.

This article is protected by copyright. All rights reserved. 


\section{Summary}

Preoperative screening

GERD and BE are often asymptomatic. Given the implications of some bariatric procedures on the development of reflux and BE and also on future cancer treatment, endoscopy plays a vital role in preoperative assessment. Other modalities, such as UGI series, are of little utility for the detection of GERD or mucosal abnormality. If significant pathology, such as esophagitis or BE is found, the patient and surgeon should strongly consider RYGB over other procedures.

\section{Effect of bariatric surgery}

Current evidence indicates that SG predisposes to de novo GERD and BE. On the other hand, RYGB is associated with resolution or reduction in length of $B E$, as well as reduced GERD. Therefore, RYGB is ideal for those with preoperative BE or GERD. Unless there is a specific indication for resection, the bypassed stomach should be left in situ, as it may be used as a conduit if an esophagectomy is required in the future.

\section{Postoperative surveillances}

Routine postoperative surveillance should strongly be considered in all patients, particularly those with SG. Reliance on symptomatology to select patients for surveillance may be unreliable and could result in missed disease.

\section{Conclusion}

$\mathrm{BE}$ is an important consideration in patients undergoing bariatric surgery. Development and progression of $B E$ is intrinsically linked with obesity, and the level of adiposity correlates with the risk. Bariatric procedures can influence the progression of $\mathrm{BE}$, and can also impact future cancer surgery. Current evidence suggests BE is more likely to develop or progress after SG, while reports have shown regression and resolution after RYGB. Screening before bariatric surgery may be valuable as, theoretically, it helps guide procedure selection and may inform future BE surveillance. Strong consideration should be given to endoscopic surveillance after SG, given the reported rates of development of BE at 5-10 years. Further prospective studies are required to strengthen these conclusions and facilitate the development of evidence-based guidelines for perioperative management of $B E$ in bariatric patients.

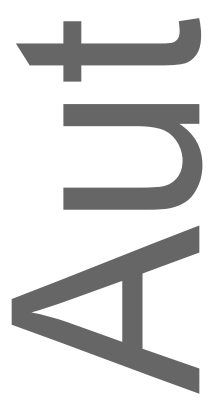

This article is protected by copyright. All rights reserved. 


\section{References}

1. Obesity and overweight. World Health Organisation, 2020. (Accessed 28 March 2020, 2020, at https://Www.who.int/news-room/fact-sheets/detail/obesity-and-overweight.)

2. Gloy VL, Briel M, Bhatt DL, et al.. Bariatric surgery versus non-surgical treatment for obesity: a systematic review and meta-analysis of randomised controlled trials. BMJ 2013;347:5934.

3. Jakobsen GS, Småstuen MC, Sandbu R, et al. . Association of bariatric surgery vs medical obesity treatment with long-term medical complications and obesity-related comorbidities. JAMA 2018;319.

4. Renehan AG, Tyson M, Egger M, Heller RF, Zwahlen M. Body-mass index and incidence of cancer: a systematic review and meta-analysis of prospective observational studies. The Lancet 2008;371:569-78

5. Chandar AK, lyer PG. Role of Obesity in the Pathogenesis and Progression of Barrett's Esophagus, Gastroenterology Clinics of North America 2015;44:249-64.

6. Thrift AP, Whiteman DC. The incidence of esophageal adenocarcinoma continues to rise: analysis of period and birth cohort effects on recent trends. Ann Oncol 2012;23:3155-62.

7. Whiteman DC, Kendall BJ. Barrett's oesophagus: epidemiology, diagnosis and clinical management. Med J Aust 2016;205:317-24.

8. Singh S, Sharma AN, Murad MH, al e. Central adiposity is associated with increased risk of esophageal inflammation, metaplasia, and adenocarcinoma: a systematic review and meta-analysis. Clin Gastroenterol Hepatol 2013;11:1407.

9. Abdallah J,Maradey-Romero C, Lewis S, Perzynski A, Fass R. The relationship between length of Barrett's oesophagus mucosa and body mass index. Aliment Pharmacol Ther 2014;41:137-44.

10. Derakhshan MH, Robertson EV, Fletcher J, al e. Mechanisms of association between BMI and dysfunction of the gastro-oesophageal barrier in patients with normal endoscopy. Gut 2012;61:33743.

11. Wu C, Mui LM, Cheung CM, al e. Obesity is associated with increased transient lower esophageal sphincter relaxation. Gastroenterology 2007;132:883-9.

12. Pandolfino JE, El-Serag $\mathrm{HB}$, Zhang $\mathrm{Q}$, al e. Obesity: a challenge to esophagogastric junction integrity. Gastroenterology 2006;130:639-49.

13. Rosen ED, Spiegelman BM. What we talk about when we talk about fat. Cell 2014;156:20-44.

14. Shulman Gt. Ectopic fat in insulin resistance, dyslipidemia, and cardiometabolic disease. $\mathrm{N}$ Engl J Med 2014;371:1131-41.

15. Sun L, Zhang Z, Xu J, Xu G, Liu X. Dietary fiber intake reduces risk of Barrett's esophagus and esophageal cancer. Critical Reviews in Food Science and Nutrition 2017;57:2749-57.

16. Chen K-, Mukaisho K-I, Sugihara H, Araki Y, Yamamoto G, Hattori T. High animal-fat intake changes the bile-acid composition of bile juices and enhances the development of Barrett's

This article is protected by copyright. All rights reserved. 
esophagus and esophageal adenocarcinoma in a rat duodenal-contents reflux model. Cancer Sci 2007;98:1683-8.

17. Ibiebele TI,Hughes MC, Nagle CM, Bain CJ, Whiteman DC, Webb PM. Dietary antioxidants and risk of Barrett's esophagus and adenocarcinoma of the esophagus in an Australian population. Int J Cancer 2013;133:214-25.

18. Katz PO, Gerson L, Vela MF. Guidelines for the diagnosis and management of gastroesophageal reflux disease. Am J Gastroenterol 2013;108:308-28.

19. Dent J, El-Serag HB, Wallander MA, al e. Epidemiology of gastro-oesophageal reflux disease: a systematic review. Gut 2005;54:710-7.

20. Abraham A, Ikramuddin S, Jahansouz C, Arafat F, Hevelone N, Leslie D. Trends in bariatric surgery: Procedure selection, revisional surgeries, and readmissions. Obes Surg 2016;26:1371-7.

21. Kang JH, Le AL. Effectiveness of bariatric surgical procedures: A systematic review and network meta-analysis of randomized controlled trials. Medicine 2017;96:e8632.

22. Ulas Biter L, Gadiot RPM, Grotenhuis BA, et al.. The Sleeve Bypass Trial: a multicentre randomized controlled trial comparing the long term outcomes of laparoscopic sleeve gastrectomy and gastric bypass for morbid obesity in terms of excess BMI loss percentage and quality of life. BMC Obesity 2015;2:30.

23. Altieri MS, Pryor AD. Gastroesophageal Reflux Disease After Bariatric Procedures. Surgical Clinics of North America 2015;95:579-91.

24. McQuaid KR, Laine L, Fennerty MB, Souza R, Spechler SJ. Systematic review: the role of bile acids in the pathogenesis of gastro-oesophageal reflux disease and related neoplasia. Aliment Pharmacol Ther 2011;34:146-65.

25. Yeung KTD, Penney N, Ashrafian L, Darzi A, Ashrafian H. Does sleeve gastrectomy expose the distal esophagus to severe reflux?: A systematic review and meta-analysis. Annals of Surgery 2020;271:257-65.

26. Pallati PK, Shaligram A, Shostrom VK, al e. Improvement in gastroesophageal reflux disease symptoms after various bariatric procedures: review of the bariatric outcomes longitudinal database. Surg Obes Relat Dis 2014;10:502-7.

27. Rawlins L, Rawlins MP, Brown CC, al e. Sleeve gastrectomy: 5 year oucomes of a single institution. Surg Obes Relat Dis 2013;9:21-5.

28. Sharma A, Aggarwal S, Ahuja V, al e. Evaluation of gastroesophageal reflux before and after sleeve gastrectomy using symptom scoring, scintigraphy, and endoscopy. Surg Obes Relat Dis 2014;10:600-5.

29. Zanotti D, Elkalaawy M, Hashemi M, Jenkinson A, Adamo M. Current Status of Preoperative Oesophago-Gastro-Duodenoscopy (OGD) in Bariatric NHS Units-a BOMSS Survey. Obesity Surgery 2016;26:2257-62.

30. Sauerland S, Angrisani L, Belachew M, et al. . Obesity surgery: Evidence-based guidelines of the European Association for Endoscopic Surgery (EAES). Surgical Endoscopy 2005;19:200-21.

This article is protected by copyright. All rights reserved. 
31. Mechanick JI, Youdim A, Jones DB, et al.. Clinical practice guidelines for the perioperative nutritional, metabolic, and nonsurgical support of the bariatric surgery patient. Surg Obes Relat Dis 2013;9:159-91.

32. American Society for Gastrointestinal Endoscopy. The role of endoscopy in the bariatric surgery patient. Gastrointestinal Endoscopy 2015;81:1063-72.

33. Zeni TM, Frantzides CT, Mahr C, et al.. Value of preoperative upper endoscopy in patients undergoing laparoscopic gastric bypass. Obesity Surgery 2006;16:142-6.

34. Mong C, Van Dam J, Morton J, Gerson L, Curet M, Banerjee S. Preoperative endoscopic screening forlaparoscopic Roux-en-Y gastric bypass has a low yield for anatomic findings. Obesity Surgery 2008;18:1067-73.

35. Korenkov M, Sauerland S, Shah S, al e. Is routine preoperative upper endoscopy in gastric banding patients really necessary? . Obes Surg 2006;16:45-7.

36. Saarinen $\mathrm{T}$, Kettunen $\mathrm{U}$, Pietilainen $\mathrm{KH}$, Juuti A. Is preoperative gastroscopy necessary before sleeve gastrectomy and Roux-en-Y gastric bypass? Surgery for Obesity and Related Diseases 2018;14:757-62.

37. Schigt A, Coblijn U, Lagarde S, Kuiken S, Scholten P, Van Wagensveld B. Is esophagogastroduodenoscopy before Roux-en-Y gastric bypass or sleeve gastrectomy mandatory? Surgery for Obesity and Related Diseases 2014;10:411-7.

38. Bennett S, Gostimir M, Shorr R, Mallick R, Mamazza J, Neville A. The role of routine preoperative upper endoscopy in bariatric surgery: a systematic review and meta-analysis. Surg 2016;12:1116-25.

39. Azagury D, Dumonceau JM, Morel P, Chassot G, Huber O. Preoperative work-up in asymptomatic patients undergoing Roux-en-Y gastric bypass: Is endoscopy mandatory? Obesity Surgery 2006;16:1304-11.

40. Humphreys LM, Meredith H, Morgan J, Norton S. Detection of asymptomatic adenocarciñoma at endoscopy prior to gastric banding justifies routine endoscopy. Obes Surg 2012;22:594

41. D'Silva M, Bhasker AG, Kantharia NS, Lakdawala M. High-Percentage Pathological Findings in Obese Patients Suggest that Esophago-gastro-duodenoscopy Should Be Made Mandatory Prior to Bariatric Surgery. Obesity Surgery 2018;28:2753-9.

42. Abou Hussein B, Khammas A, Shokr M, et al.. Role of routine upper endoscopy before bariatric surgery in the Middle East population: A review of 1278 patients. Endoscopy International Open 2018;6:E1171-E6.

43. D'Hondt $M$, Steverlynck $M$, Pottel $H$, et al.. Value of preoperative esophagogastroduodenoscopy in morbidly obese patients undergoing laparoscopic Roux-en-Y gastric bypass. Acta Chirurgica Belgica 2013;113:249-53.

44. Moulla Y, Lyros O, Mehdorn M, et al.. Preoperative Upper-GI Endoscopy Prior to Bariatric Surgery: Essential or Optional? Obesity Surgery 2020.

This article is protected by copyright. All rights reserved. 
45. Ozeki KA, Tran SA, Cheung R, Eisenberg D. Preoperative Endoscopic Findings in Veterans Undergoing Bariatric Surgery: Prevalence and Predictors of Barrett's Esophagus. Obesity Surgery 2020;30:657-63.

46. Schneider R, Lazaridis I, Kraljevic M, Beglinger C, Wolnerhanssen B, Peterli R. The impact of preoperative investigations on the management of bariatric patients; results of a cohort of more than 1200 cases. Surgery for Obesity and Related Diseases 2018;14:693-9.

47. Sharaf RN, Weinshel EH, Bini EJ, Rosenberg J, Sherman A, Ren CJ. Endoscopy plays an important preoperative role in bariatric surgery. Obesity Surgery 2004;14:1367-72.

48. Wolter S, Dupree A, Miro J, et al. . Upper Gastrointestinal Endoscopy prior to Bariatric Surgery-Mandatory or Expendable? An Analysis of 801 Cases. Obesity Surgery 2017;27:1938-43.

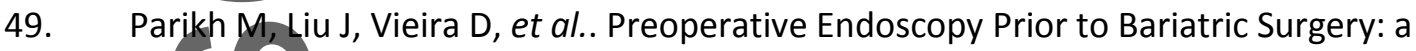
Systematic Review and Meta-Analysis of the Literature. Obesity Surgery 2016;26:2961-6.

50. Burton PR, Ooi GJ, Laurie C, et al.. Diagnosis and Management of Oesophageal Cancer in Bariatric Surgical Patients. Journal of gastrointestinal surgery : official journal of the Society for Surgery of the Alimentary Tract 2016;20:1683-91.

51. Kuruba R, Jawad M, Karl RC, Murr MM. Technique of resection of esophageal adenocarcinoma after Roux-en-Y gastric bypass and literature review of esophagogastric tumors after bariatric procedures. Surg 2009;5:576-81.

52. Adil MT, Al-taan O, Rashid F, et al. A Systematic Review and Meta-Analysis of the Effect of Roux-en-Y Gastric Bypass on Barrett's Esophagus. Obesity Surgery 2019;29:3712-21.

53. Csendes A, Burgos AM, Smok G, Burdiles P, Henriquez A. Effect of gastric bypass on Barrett's esophagus and intestinal metaplasia of the cardia in patients with morbid obesity. Journal of Gastrointestinal Surgery 2006;10:259-64.

54. Signorini F, Viscido G, Bocco MCA, Obeide L, Moser F. Impact of Gastric Bypass on Erosive Esophagitis and Barret's Esophagus. Obesity Surgery 2020.

55. Felsenreich DM, Langer FB, Bichler C, et al.. Roux-en-Y Gastric Bypass as a Treatment for Barrett'sEsophagus after Sleeve Gastrectomy. Obesity Surgery 2019.

56. Varela JE. Barrett's esophagus: A late complication of laparoscopic adjustable gastric banding. Obesity Surgery 2010;20:244-6.

57. Rosenthal RJ, Szomstein S, Kennedy Cl, Soto FC, Zundel N. Laparoscopic surgery for morbid obesity: 1,001 Consecutive bariatric operations performed at the Bariatric Institute, Cleveland Clinic Florida. Obesity Surgery 2006;16:119-24.

58. Gehwolf P, Kienzl-Wagner K, Cakar-Beck F, Schafer A, Wykypiel H. Laporoscopic adjustable gastric banding: An underestimated risk factor for the development of esophageal cancer? A nationwide survey. Diseases of the Esophagus 2018;31 (Supplement 1):195.

59. Shaheen NJ, Falk GW, lyer PG, Gerson LB. ACG Clinical Guideline: Diagnosis and management of Barrett's esophagus. Am J Gastroenterol 2016;111:30-50.

This article is protected by copyright. All rights reserved. 
60. Fried M, Yumuk V, Oppert J-M, et al. Interdisciplinary European guidelines on metabolic and bariatric surgery. Obes Facts 2013;6:449-68.

61. For which populations is screening for BO cost-effective? Cancer COuncil Australia, 2014. (Accessed 14 May, 2020, at https://wiki.cancerorg.au/australia/Clinical_question:For_which_populations_is_screening_for_BO_ cost-effective\%3F)

62. Qumseya BJ, Sultan S, Bain P, et al.. ASGE guideline on screening and surveillance of Barrett's esophagus. Gastrointestinal Endoscopy 2019;90:335-59.

63. Genco A, Soricelli E, Casella G, et al.. Gastroesophageal reflux disease and Barrett's esophagus after laparoscopic sleeve gastrectomy: a possible, underestimated long-term complication. Surgery for Obesity and Related Diseases 2017;13:568-74.

64. Soricelli E, Casella G, Baglio G, Maselli R, Ernesti I, Genco A. Lack of correlation between gastroesophageal reflux disease symptoms and esophageal lesions after sleeve gastrectomy. Surgery for Obesity and Related Diseases 2018;14:751-6.

65. Bradley DD, Louie BE, Chen J, Aye RW, McMahon R, Farivar AS. The effect of concurrent esophageal pathology on bariatric surgical planning. Journal of gastrointestinal surgery : official journal of the Society for Surgery of the Alimentary Tract 2015;19:111-5; discussion 5-6.

66. Carabotti M, Avallone M, Cereatti F, et al. Usefulness of Upper Gastrointestinal Symptoms as a Driver to Prescribe Gastroscopy in Obese Patients Candidate to Bariatric Surgery. A Prospective Study. Obesity Surgery 2016;26:1075-80.

67. Coblijn UK, Kuiken SD, Van Wagensveld BA. Comment on: Is esophagogastroduodenoscopy before Roux-en-Y gastric bypass or sleeve gastrectomy mandatory? Surgery for Obesity and Related Diseases 2015;11:1192-3.

68. Csendes A, Burgos AM, Smok G, Beltran M. Endoscopic and histologic findings of the foregut in 426 patients with morbid obesity. Obesity surgery : the official journal of the American Society for Bariatric Surgery and of the Obesity Surgery Society of Australia and New Zealand 2007;17:28-34.

69. Endo $\mathrm{Y}$, Ohta M, Tada K, et al. Clinical significance of upper gastrointestinal endoscopy before laparoscopic bariatric procedures in Japanese patients. Surgery Today 2019;49:27-31.

70. Estevez-Fernandez S, Sanchez-Santos R, Marino-Padin E, Gonzalez-Fernandez S, TurnesVazquez J. Esophagogastric pathology in morbid obese patient: Preoperative diagnosis and influence in the selection of surgical technique. Revista Espanola de Enfermedades Digestivas 2015;107:408-

12.

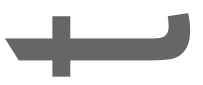

71. Fernandes SR, Meireles LC, Carrilho-Ribeiro L, Velosa J. The Role of Routine Upper Gastrointestinal Endoscopy Before Bariatric Surgery. Obesity Surgery 2016;26:2105-10.

72. Heimgartner B, Herzig M, Borbely Y, Kroll D, Nett P, Tutuian R. Symptoms, endoscopic findings and reflux monitoring results in candidates for bariatric surgery. Digestive and Liver Disease 2017; $49: 750-6$.

This article is protected by copyright. All rights reserved. 
73. Kavanagh R, Smith J, Bashir U, Jones D, Avgenakis E, Nau P. Optimizing bariatric surgery outcomes: a novel preoperative protocol in a bariatric population with gastroesophageal reflux disease. Surgical Endoscopy 2019.

74. Masci E, Viaggi P, Mangiavillano B, et al. No increase in prevalence of Barrett's oesophagus in a surgical series of obese patients referred for laparoscopic gastric banding. Dig Liver Dis 2011;43:613-5.

75. Munoz R, Ibanez L, Salinas J, et al. Importance of routine preoperative upper GI endoscopy: Why all patients should be evaluated? Obesity Surgery 2009;19:427-31.

76. Santo MA, Quintanilha SR, Mietti CA, Kawamoto FM, Marson AG, de Cleva R. Endoscopic Changes Related to Gastroesophageal Reflux Disease: Comparative Study among Bariatric Surgery Patients. Arquivos brasileiros de cirurgia digestiva : $A B C D=$ Brazilian archives of digestive surgery 2015;28:36-8.

77. Schlottmann F, Sadava EE, Reino R, Galvarini M, Buxhoeveden R. Preoperative endoscopy in bariatric patients may change surgical strategy. Acta Gastroenterologica Latinoamericana 2017;47:117-21.

78. Suter M.Comment on: Evaluation of gastroesophageal reflux before and after laparoscopic sleeve gastrectomy using symptom scoring, scintigraphy and endoscopy. Surgery for Obesity and Related Diseases 2014;10:605-6.

79. Braghetto I, Csendes A. Prevalence of Barrett's Esophagus in Bariatric Patients Undergoing Sleeve Gastrectomy. Obesity Surgery 2016;26:710-4.

80. Csendes A, Orellana O, Martinez G, Burgos AM, Figueroa M, Lanzarini E. Clinical, Endoscopic, and Histologic Findings at the Distal Esophagus and Stomach Before and Late (10.5 Years) After Laparoscopic Sleeve Gastrectomy: Results of a Prospective Study with 93\% Follow-Up. Obesity Surgery 2019;29:3809-17.

81. Felsenreich DM, Kefurt R, Schermann M, et al. Reflux, Sleeve Dilation, and Barrett's Esophagus after Laparoscopic Sleeve Gastrectomy: Long-Term Follow-Up. Obesity Surgery 2017;27:3092-101.

82. Felsenreich DM, Ladinig LM, Beckerhinn P, et al. Update: 10 Years of Sleeve Gastrectomy-the First 103 Patients. Obesity Surgery 2018;28:3586-94.

83. Sebastianelli L, Benois M, Vanbiervliet G, et al. Systematic Endoscopy 5 Years After Sleeve Gastrectomy Results in a High Rate of Barrett's Esophagus: Results of a Multicenter Study. Obesity Surgery 2019;29:1462-9.

84. Andrew B, Alley JB, Aguilar CE, Fanelli RD. Barrett's esophagus before and after Roux-en-Y gastric bypass for severe obesity. Surgical Endoscopy 2018;32:930-6.

85. Braghetto1, Korn O, Csendes A, Gutierrez L, Valladares H, Chacon M. Laparoscopic treatment of obese patients with gastroesophageal reflux disease and Barrett's esophagus: A prospective study. Obesity Surgery 2012;22:764-72.

86. Gorodner V, Buxhoeveden R, Clemente G, Sanchez C, Caro L, Grigaites A. Barrett's esophagus after Roux-en-Y gastric bypass: does regression occur? Surgical Endoscopy 2017;31:1849-54.

This article is protected by copyright. All rights reserved. 
87. Houghton SG, Romero Y, Sarr MG. Effect of Roux-en-Y gastric bypass in obese patients with Barrett's esophagus: attempts to eliminate duodenogastric reflux. Surgery for Obesity and Related Diseases 2008;4:1-4.

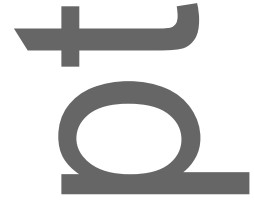

\begin{tabular}{|c|c|c|c|}
\hline Guideline & Year & Recommendation & $\begin{array}{l}\text { Selective or } \\
\text { routine }\end{array}$ \\
\hline $\begin{array}{l}\text { The American Association of Clinical } \\
\text { Endocrinologists, the Obesity Society, } \\
\text { and the American Society for Metabolic } \\
\text { and Bariatric Surgery } \\
\text { (AACE/TOS/ASMBS) })^{31}\end{array}$ & 2013 & $\begin{array}{l}\text { Clinically significant GI symptoms should be evaluated before } \\
\text { bariatric surgery with imaging studies, UGI series, or } \\
\text { endoscopy (Grade D recommendation) }\end{array}$ & Selective \\
\hline $\begin{array}{l}\text { The European Association for Endoscopic } \\
\text { Surgery (EAES) }\end{array}$ & 2005 & $\begin{array}{l}\text { Upper GI endoscopy or upper GI series is advisable for all } \\
\text { bariatric procedures (Grade C recommendation), but is } \\
\text { strongly recommended for gastric bypass patients (Grade } \\
\text { B recommendation) }\end{array}$ & Routine \\
\hline $\begin{array}{l}\text { The American Society for Gastrointestinal } \\
\text { Endoscopy (ASGE) })^{32}\end{array}$ & 2015 & $\begin{array}{l}\text { The decision to perform preoperative endoscopy should be } \\
\text { individualized in patients scheduled to undergo bariatric } \\
\text { surgery after a thorough discussion with the surgeon, } \\
\text { taking into consideration the type of bariatric procedure } \\
\text { performed (low-quality evidence) } \\
\text { Patients with symptoms of GERD, such as heartburn, } \\
\text { regurgitation, dysphagia, or any postprandial symptoms } \\
\text { that suggest a foregut pathology and/or who chronically } \\
\text { use antisecretory medications should have a UGI } \\
\text { endoscopic evaluation before bariatric surgery. }\end{array}$ & Selective \\
\hline
\end{tabular}

Abbreviations: $\mathrm{Gl}$, gastrointestinal; UGI, upper gastrointestinal.

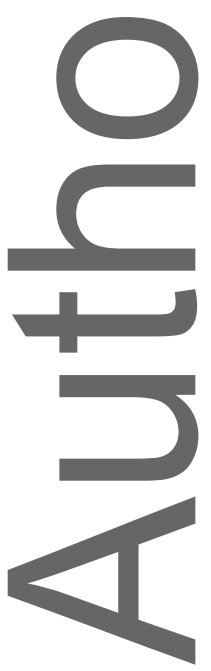

This article is protected by copyright. All rights reserved. 
Table 2. Studies examining preoperative screening endoscopy for Barrett's esophagus in bariatric surgical patients

\begin{tabular}{|c|c|c|c|c|c|c|c|c|}
\hline Study & Type & $N$ & $N$ demographics & $\begin{array}{l}\text { Population } \\
\text { included }\end{array}$ & $\begin{array}{c}\text { Prevalence of } \\
\text { BE }\end{array}$ & Normal & $\begin{array}{l}\text { Clinical } \\
\text { impact }\end{array}$ & $\begin{array}{l}\text { Recommendation } \\
\text { for endoscopy }\end{array}$ \\
\hline $\begin{array}{l}\text { Abou } \\
\text { Hussein }\end{array}$ & Retrospective & 1278 & $\begin{array}{l}61 \% \text { female } \\
\mathrm{BMI}=43.7 \pm 8\end{array}$ & All bariatric & $3.0 \%$ & $10.6 \%$ & & Routine \\
\hline Azagury, ${ }^{39}$ & ctive & 319 & & $\begin{array}{l}\text { Asymptomatic } \\
\text { bariatric }\end{array}$ & $0.31 \%$ & $54 \%$ & $4 \%$ & Selective \\
\hline $\begin{array}{l}\text { Bradley, } 2015 \\
65\end{array}$ & Retrospective & 79 & $\begin{array}{l}76 \% \text { female, } \\
\text { median } \\
\text { BMI }=44.6\end{array}$ & $\begin{array}{l}\text { All bariatric } \\
\text { with reflux, } \\
\text { dysphagia, or } \\
\text { hiatal hernia }\end{array}$ & $16.4 \%$ & - & $19 \%$ & Selective \\
\hline Carabotti $^{66}$ & & 142 & $\begin{array}{l}82 \% \text { female, } \\
\text { median } \mathrm{BMI}= \\
44\end{array}$ & All bariatric & 0 & $53 \%$ & $3.5 \%$ & Routine \\
\hline Coblijn $^{67}$ & Prospective & 523 & $\begin{array}{l}76.5 \% \text { female, } \\
\text { mean } \mathrm{BMI}= \\
46.5\end{array}$ & $\begin{array}{l}\text { Primary } \\
\text { bariatric }\end{array}$ & $1 \%$ & $49 \%$ & $62 \%$ & $\begin{array}{l}\text { Not } \\
\text { recommended }\end{array}$ \\
\hline Csendes $^{68}$ & Prospective & 426 & $78 \%$ female & All bariatric & $5.8 \%$ & $45 \%$ & - & Routine \\
\hline D'Hondt $^{43}$ & Retrospective & 652 & $\begin{array}{l}\text { Age } 39.5 \pm \\
11.3,70.9 \% \\
\text { female, } \mathrm{BMI}= \\
42.8 \pm 5.0\end{array}$ & $\begin{array}{l}\text { Consecutive } \\
\text { RYGB }\end{array}$ & $0.8 \%$ & $31.9 \%$ & $7.8 \%$ & Routine \\
\hline D'Silva $^{41}$ & Prospective & 675 & $\begin{array}{l}\text { Age } 45 \pm 9.1, \\
\mathrm{BMI}=43.9 \pm \\
6.9\end{array}$ & All bariatric & $1.8 \%$ & $78.5 \%$ & $9.9 \%$ & Routine \\
\hline Endo $^{69}$ & Retrospective & 155 & $\begin{array}{l}59 \% \text { female, } \\
\text { BMI } 45 \pm 8\end{array}$ & All bariatric & $0.6 \%$ & $34 \%$ & $10 \%$ & Routine \\
\hline $\begin{array}{l}\text { Estevez- } \\
\text { Fernandez }^{70}\end{array}$ & Retrospective & 331 & $\begin{array}{l}82 \% \text { female, } \\
\text { mean } \mathrm{BMI}= \\
47.5\end{array}$ & All bariatric & $0.6 \%$ & - & $52.6 \%$ & Routine \\
\hline Fernandes $^{71}$ & Retrospective & 613 & $\begin{array}{l}78 \% \text { female, } \\
\text { mean = BMI } \\
44.7\end{array}$ & $\begin{array}{l}\text { All bariatric } \\
\text { (selective } \\
\text { endoscopy) }\end{array}$ & $0.5 \%$ & $43.7 \%$ & - & - \\
\hline Heimgartner & spec & 100 & $\begin{array}{l}68 \% \text { female, } \\
\text { mean } \mathrm{BMI}= \\
44.9 \pm 6.9\end{array}$ & All bariatric & $6 \%$ & $29 \%$ & - & Routine \\
\hline Humphreys $^{40}$ & Retrospective & 371 & & $\begin{array}{l}\text { LAGB } \\
\text { (selective } \\
\text { endoscopy) }\end{array}$ & $0.8 \%$ & $56 \%$ & - & Routine \\
\hline Kavanagh $^{73}$ & Retrospective & 133 & $\begin{array}{l}68 \% \text { female, } \\
\text { mean } \mathrm{BMI}= \\
46.8\end{array}$ & $\begin{array}{l}\text { All } \\
\text { symptomatic } \\
\text { bariatric }\end{array}$ & $8 \%$ & - & $69.9 \%$ & Selective \\
\hline Masci $^{74}$ & Prospective & 1049 & $\begin{array}{l}78 \% \text { female, } \\
\text { mean } \mathrm{BMI}= \\
45.1 \pm 4.6\end{array}$ & $\begin{array}{l}\text { LAGB } \\
\text { (selective } \\
\text { endoscopy) }\end{array}$ & 0 & $91.8 \%$ & $2.3 \%$ & - \\
\hline Mong $^{34}$ & Petroan & 272 & $\begin{array}{l}87 \% \text { female, } \\
\text { BMI }=48 \pm \\
7.95\end{array}$ & $\begin{array}{l}\text { All bariatric } \\
\text { (selective } \\
\text { endoscopy) }\end{array}$ & $3.7 \%$ & $88 \%$ & $0.3 \%$ & Routine \\
\hline Moulla $^{44}$ & Retrospective & 636 & $\begin{array}{l}\mathrm{BMI}=49 \\
\text { (range 31-92) }\end{array}$ & $\begin{array}{l}\text { All bariatric } \\
\text { (selective } \\
\text { endoscopy) }\end{array}$ & $15.0 \%$ & - & $1.6 \%$ & Selective \\
\hline Munoz $^{75}$ & $\overline{\text { Retrospective }}$ & 626 & $\begin{array}{l}72 \% \text { female, } \\
\text { BMI } 42 \pm 6.5\end{array}$ & $\begin{array}{l}\text { RYGB } \\
\text { (selective } \\
\text { endoscopy) }\end{array}$ & $0.16 \%$ & $54 \%$ & $>45 \%$ & Routine \\
\hline Ozeki $^{45}$ & Retrospective & 260 & $\begin{array}{l}\text { Age } 54.0 \pm 9.0, \\
25 \% \text { female, } \\
\mathrm{BMI}=44.9 \pm \\
7.0\end{array}$ & $\begin{array}{l}\text { All Veterans } \\
\text { undergoing } \\
\text { RYGB or SG } \\
\text { (routine) }\end{array}$ & $7.4 \%$ & $33 \%$ & - & Selective \\
\hline Parikh $^{49}$ & & 6616 & $\begin{array}{l}\text { Mean } \\
\text { BMI = 47 } \pm 3.2\end{array}$ & $\begin{array}{l}\text { Review of } 28 \\
\text { studies on } \\
\text { preoperative } \\
\text { endoscopy }\end{array}$ & $0.1 \%$ & $92.4 \%$ & $7.6 \%$ & Selective \\
\hline Saarinen $^{36}$ & Retrospective & 1275 & $\begin{array}{l}\text { Age } 48.5 \pm 9.1, \\
72.6 \% \text { female, } \\
\text { BMI }=46.1 \pm \\
7.0\end{array}$ & $\begin{array}{l}\text { All bariatric } \\
\text { (selective } \\
\text { endoscopy) }\end{array}$ & $\begin{array}{c}3.7 \%(2.2 \% \\
\text { asymptomatic) }\end{array}$ & $50.7 \%$ & $24.6 \%$ & Routine \\
\hline Santo $^{76}$ & Retrospective & 717 & & All bariatric & $0.28 \%$ & - & - & - \\
\hline
\end{tabular}

This article is protected by copyright. All rights reserved. 


\begin{tabular}{|c|c|c|c|c|c|c|c|c|}
\hline & & & & $\begin{array}{l}\text { (selective } \\
\text { endoscopy) }\end{array}$ & & & & \\
\hline Schigt $^{37}$ & Prospective & 523 & $\begin{array}{l}\text { Age } 44.3, \\
76.7 \% \text { female, } \\
\text { BMI }=46.6\end{array}$ & $\begin{array}{l}\text { All bariatric } \\
\text { (routine } \\
\text { endoscopy) }\end{array}$ & $1.3 \%$ & $49.1 \%$ & - & Selective \\
\hline Schlottmann ${ }^{77}$ & $\overline{\text { Retrosp }}$ & 193 & $\begin{array}{l}64 \% \text { female, } \\
\text { mean = BMI } \\
44.5\end{array}$ & $\begin{array}{l}\text { All bariatric } \\
\text { (selective } \\
\text { endoscopy) }\end{array}$ & $1.6 \%$ & $64 \%$ & - & Routine \\
\hline Schneider $^{46}$ & Retrospective & 1190 & & $\begin{array}{l}\text { All bariatric } \\
\text { (selective } \\
\text { endoscopy) }\end{array}$ & $0.4 \%$ & $39.5 \%$ & $2.4 \%$ & Routine \\
\hline Sharaf $^{47}$ & Retrospective & 195 & $\begin{array}{l}\text { Age } 41.2 \\
78.5 \% \text { female, } \\
\text { BMI }=48.9\end{array}$ & $\begin{array}{l}\text { All bariatric } \\
\text { (selective } \\
\text { endoscopy) }\end{array}$ & $3.1 \%$ & $10.3 \%$ & $61.5 \%$ & Routine \\
\hline Soricelli $^{64}$ & Prospective & 144 & $\begin{array}{l}\text { Mean } \\
\text { BMI = 46.2 } \pm \\
7.2\end{array}$ & $\begin{array}{l}\text { SG (routine } \\
\text { endoscopy) }\end{array}$ & $13 \%$ & - & - & $\begin{array}{l}\text { Consider wider } \\
\text { screening }\end{array}$ \\
\hline Suter $^{78}$ & & 345 & $\begin{array}{l}80 \% \text { female, } \\
\text { mean } \mathrm{BMI}= \\
44.7\end{array}$ & $\begin{array}{l}\text { Patients being } \\
\text { evaluated for } \\
\text { bariatric } \\
\text { surgery }\end{array}$ & $1.2 \%$ & - & - & - \\
\hline Wolter $^{48}$ & Retrospective & 801 & $\begin{array}{l}\text { Age } 43.8 \pm \\
11.4, \mathrm{BMI}= \\
50.1 \pm 12.7\end{array}$ & $\begin{array}{l}\text { All bariatric } \\
\text { (routine } \\
\text { endoscopy) }\end{array}$ & $2.1 \%$ & $34.3 \%$ & - & Routine \\
\hline Zeni $^{33}$ & Retrospective & 169 & $\begin{array}{l}82 \% \text { female, } \\
\text { mean } \mathrm{BMI}= \\
49.7\end{array}$ & All bariatric & $1.3 \%$ & $33.3 \%$ & $9.4 \%$ & Routine \\
\hline
\end{tabular}

Abbreviations:-BMI, body mass index; RYGB, Roux-en-Y gastric bypass; SG, sleeve gastrectomy; LAGB, laparoscopic adjustable gastric band

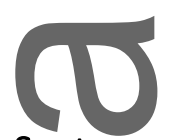

Table 3. Systematic reviews on bariatric procedures and their impact on BE

\begin{tabular}{|c|c|c|c|c|}
\hline $\begin{array}{l}\text { Systematic } \\
\text { review }\end{array}$ & $\mathbf{A i}$ & Study details & Results & Conclusions \\
\hline Adil, $2019^{52}$ & $\begin{array}{l}\text { Effect on RYGB } \\
\text { on BE with } \\
\text { pre- and } \\
\text { postendoscop } \\
\text { y and biopsy }\end{array}$ & $\begin{array}{l}\text { Eight studies } \\
10,779 \text { patients } \\
117 \text { patients with } \mathrm{BE} \\
\text { with follow-up }>1 \\
\text { year }\end{array}$ & $\begin{array}{l}\text { Regression of BE after RYGB (risk difference }-0.56 \\
\text { (95\% CI: }-0.69 \text { to }-0.43), P<0.001) \text { : } \\
\text { - Short-segment BE }(-0.51(95 \% \mathrm{CI}:-0.68 \text { to - } \\
0.33), P<0.001) \\
\text { - Long-segment BE }(-0.46 \text { (95\% CI: }-0.71 \text { to - } \\
0.21), P<0.001) \\
\text { Strongly associated with regression of BE versus } \\
\text { progression (OR }=31.2 \text { ( } 95 \% \text { CI: } 11.37 \text { to } 85.63) \text {, } \\
P<0.001) \\
\text { Improvement in GERD }(-0.93 \text { (95\% CI: }-1.04 \text { to - } \\
0.81), P<0.001\end{array}$ & $\begin{array}{l}\text { RYGB improves } \\
\text { BE significantly } \\
\text { at a }>1 \text {-year } \\
\text { follow-up }\end{array}$ \\
\hline $\begin{array}{l}\text { Yeung, } \\
2020^{25}\end{array}$ & $\begin{array}{l}\text { Effect of SG on } \\
\text { GERD, } \\
\text { esophagitis, } \\
\text { and BE to } \\
\text { clarify long- } \\
\text { term clinical } \\
\text { sequelae }\end{array}$ & $\begin{array}{l}46 \text { studies (all GERD } \\
\text { related pathology) } \\
10,718 \text { patients } \\
\text { Five studies with BE } \\
\text { with long-term } \\
\text { results }\end{array}$ & $\begin{array}{l}\text { The long-term prevalence of BE was } 8 \% \text {. High } \\
\text { heterogeneity }\left(I^{2}=94.1 \%\right) \\
\text { Increase in postoperative GERD after the sleeve was } \\
19 \% \\
\text { De novo reflux was } 23 \% \\
\text { The long-term prevalence of esophagitis was } 28 \% \\
4 \% \text { required conversion to RYGB for severe reflux } \\
\text { Symptoms do not always correlate with pathology }\end{array}$ & $\begin{array}{l}\text { Prevalence of BE } \\
\text { following SG is } \\
\text { significant } \\
\text { Surgical decision } \\
\text { making and } \\
\text { consent should } \\
\text { consider these } \\
\text { long-term } \\
\text { complications }\end{array}$ \\
\hline
\end{tabular}


Table 4. Studies examining effect of SG on incidence of BE

\begin{tabular}{|c|c|c|c|c|c|}
\hline Ref. & $N$ & Population & Follow-up & $\mathrm{BE}$ & Results \\
\hline $\begin{array}{l}\text { Braghetto, } 2016 \\
\text { (prospective) }^{79}\end{array}$ & 231 & $\begin{array}{l}\text { Patients with normal preoperative } \\
\text { endoscopy } \\
72.7 \% \text { female, } \mathrm{BMI}=38.5 \pm 3.1\end{array}$ & $5-6$ years & $\begin{array}{l}1.2 \% \\
\text { de novo }\end{array}$ & $\begin{array}{l}\text { Postoperatively: } \\
\text { - } \text { BE in } 3(1.2 \%) \text { (between } 5 \text { and } 6) \\
\text { years postoperatively } \\
\text { - Reflux symptoms in } 57(23.2 \%) \\
\text { - Erosive esophagitis in } 38(15.5 \%)\end{array}$ \\
\hline $\begin{array}{l}\text { Csendes, } 2019 \\
\text { (prospective) }^{80}\end{array}$ & & $\begin{array}{l}\text { Consecutive SG without (group 1) } \\
\text { and with (group 2) reflux }\end{array}$ & 1.6 years & $\begin{array}{l}3.8-4.5 \% \\
\text { de novo }\end{array}$ & $\begin{array}{l}\text { Group 1: Two developed BE }(3.8 \%) \text {, } \\
\text { 58.5\% developed GERD } \\
\text { Group 2: Two developed BE }(4.5 \%) \text {, } \\
13.5 \% \text { had a resolution of GERD }\end{array}$ \\
\hline $\begin{array}{l}\text { Felsenreich, } \\
2017 \\
\text { (prospective) }^{81}\end{array}$ & 43 & $\begin{array}{l}\text { Patients with primary SG } 10 \text { years } \\
\text { prior, without reflux or } \mathrm{HH} \\
\text { preoperative }\end{array}$ & $10+$ years & $\begin{array}{l}15 \% \\
\text { de novo }\end{array}$ & $\begin{array}{l}\text { De novo Barrett's in } 15 \% \text {, de novo hiatal } \\
\text { hernia in } 45 \% \text {. } \\
\text { Siz patients converted to RYGB due to } \\
\text { reflux }(14.0 \%) \text { over } 130 \text { months. } \\
\text { Lower GI quality of life and higher } \\
\text { reflux symptom index in sleeve } \\
\text { patients. }\end{array}$ \\
\hline $\begin{array}{l}\text { Felsenreich, } \\
2018 \\
\text { (prospective) }^{82}\end{array}$ & 65 & $\begin{array}{l}\text { Consecutive SG between January } \\
2003 \text { and December } 2006\end{array}$ & $10+$ years & $\begin{array}{l}9.2 \% \\
\text { de novo }\end{array}$ & $\begin{array}{l}44 \text { patients had follow-up gastroscopy, } \\
\text { of which six had Barrett's } \\
\text { metaplasia }\end{array}$ \\
\hline $\begin{array}{l}\text { Genco, } 2017 \\
\text { (prospective) }^{63}\end{array}$ & 110 & $\begin{array}{l}\text { Primary SG between July } 2007 \text { and } \\
\text { January } 2010\end{array}$ & 58 months & $\begin{array}{l}17.2 \% \\
\text { de novo }\end{array}$ & $\begin{array}{l}\text { Increase in erosive esophagitis, GERD } \\
\text { symptoms }(68.1 \% \text { versus } 33.6 \% \text {, } \\
P<0.001), \text { and PPI intake }(57.2 \% \\
\text { versus } 19.1 \%, P<0.0001) \text {. } \\
\text { Endoscopic findings not related to } \\
\text { symptoms. }\end{array}$ \\
\hline $\begin{array}{l}\text { Sebastianelli, } \\
2019 \\
\text { (prospective) }^{83}\end{array}$ & 90 & $\begin{array}{l}\text { SG who had undergone surgery at } \\
\text { least } 5 \text { years before without } \\
\text { preoperative BE }\end{array}$ & $\begin{array}{l}78 \pm 15 \\
\text { months }\end{array}$ & $\begin{array}{l}18.8 \% \\
\text { de novo }\end{array}$ & $\begin{array}{l}\text { Increase in GERD symptoms ( } 22 \% \text { to } \\
76 \%) \text {, erosive esophagitis }(10 \% \text { to } \\
41 \%) \text {, and PPI use ( } 22 \% \text { to } 52 \%) \text {, all } \\
P<0.05 \text {. }\end{array}$ \\
\hline
\end{tabular}

Abbreviations: RYGB, Roux-en-Y gastric bypass; SG, sleeve gastrectomy; BE, Barrett's esophagus; GERD, gastroesophageal reflux disease; PPI, proton pump inhibitor; EE, erosive esophagitis

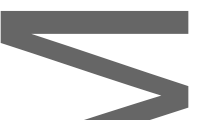

Table 5. Studies examining effect of RYGB on incidence of $B E$

\begin{tabular}{|c|c|c|c|c|c|c|}
\hline Ref. & $\begin{array}{l}\text { Type of } \\
\text { gastric } \\
\text { bypass }\end{array}$ & $N$ & Population & $\begin{array}{l}\text { Follow- } \\
\text { up }\end{array}$ & $\mathrm{BE}$ & Results \\
\hline $\begin{array}{l}\text { Andrew, } 2018 \\
\text { (retrospective) }^{84}\end{array}$ & RYGB & 14 & $\begin{array}{l}\text { Patients with proven } \\
\text { BE who underwent } \\
\text { RYGB (September } \\
\text { 2011-May 2015). }\end{array}$ & 1 year & $\begin{array}{l}42.9 \% \\
\text { resolution }\end{array}$ & $\begin{array}{l}\text { All short-segment BE. } \\
6 / 14(42.9 \%) \text { complete } \\
\text { regression to normal } \\
13 / 14(92.8 \%) \text { complied } \\
\text { with PPI for } 1 \text { year }\end{array}$ \\
\hline $\begin{array}{l}\text { Braghetto, } 2012 \\
\text { (retrospective) }^{85}\end{array}$ & $\begin{array}{l}\text { Resectional } \\
\text { RYGB }\end{array}$ & 21 & $\begin{array}{l}\text { Patients undergoing } \\
\text { antireflux } \\
\text { operations } \\
\text { (including } \\
\text { LRRYGB) }\end{array}$ & 1 year & $\begin{array}{l}61.9 \% \\
\text { regression }\end{array}$ & $\begin{array}{l}\text { Regression in IM in } 13 \\
(61.9 \%) \\
\text { Significant reduction in } \\
\text { acid reflux, symptoms } \\
\text { and erosive esophagitis }\end{array}$ \\
\hline $\begin{array}{l}\text { Csendes, } 2006 \\
\text { (retrospective) }^{53}\end{array}$ & $\begin{array}{l}\text { Resectional } \\
\text { RYGB }\end{array}$ & 557 & $\begin{array}{l}\text { August } 1999 \text { to } \\
\text { October2004 }\end{array}$ & 2 years & $\begin{array}{l}\text { SSBE: } 57 \% \\
\text { regression } \\
\text { LSBE: } 20 \% \\
\text { regression }\end{array}$ & $\begin{array}{l}\text { Twelve patients with BE } \\
\text { (2.1\%): seven with } \\
\text { SSBE and five with } \\
\text { LSBE } \\
\text { Postoperative: } \\
\text { - Regression of } 57 \% \\
\text { with SSBE } \\
\text { - Regression of } 20 \% \\
\text { with LSBE } \\
\text { - Reflux esophagitis } \\
\text { resolved in all patients }\end{array}$ \\
\hline
\end{tabular}

This article is protected by copyright. All rights reserved. 


\begin{tabular}{|c|c|c|c|c|c|c|}
\hline & & & & & & postoperatively \\
\hline $\begin{array}{l}\text { Felsenreich, } 2019 \\
\text { (retrospective) }^{55}\end{array}$ & $\begin{array}{l}\text { Revision } \\
\text { RYGB }\end{array}$ & 10 & $\begin{array}{l}\text { Patients converted to } \\
\text { RYGB due to BE } \\
\text { after SG }\end{array}$ & $\begin{array}{l}33.4 \\
\text { months }\end{array}$ & $\begin{array}{l}80 \% \\
\text { resolution }\end{array}$ & $\begin{array}{l}\text { Decrease in a } 24-\mathrm{h} \text { mean } \\
\text { acid exposure }(36.8 \% \text { to } \\
3.8 \%) \text { and mean } \\
\text { DeMeester from } 100 \text { to } \\
16.3 \text {. }\end{array}$ \\
\hline $\begin{array}{l}\text { Gorodner, } 2017 \\
\text { (retrospective) }^{86}\end{array}$ & RYGB & 11 & $\begin{array}{l}\text { Bariatric cases with } \\
\text { baseline BE }\end{array}$ & $\begin{array}{l}41 \pm 31 \\
\text { months }\end{array}$ & $\begin{array}{l}36 \% \\
\text { resolution }\end{array}$ & $\begin{array}{l}\text { Nine SSBE and two SBE } \\
\text { Average length of BE } 2.1 \pm \\
1.6 \mathrm{~cm} \text { preoperatively } \\
\text { and } 1.2 \pm 1.2 \mathrm{~cm} \\
\text { postoperatively }(P> \\
0.05) \\
\text { Remission in four cases } \\
(36 \%) \text { : three SSBE and } \\
\text { one LSBE. }\end{array}$ \\
\hline $\begin{array}{l}\text { Houghton, 20 } \\
\text { (retrospective }\end{array}$ & & 5 & $\begin{array}{l}\text { Patients with Bx } \\
\text { proven LSBE } \\
\text { undergoing RYGB, } \\
\text { with a }>1 \text {-year } \\
\text { follow-up }\end{array}$ & $\begin{array}{l}34 \\
\text { months }\end{array}$ & $\begin{array}{l}40 \% \\
\text { resolution } \\
80 \% \\
\text { decreased } \\
\text { length }\end{array}$ & $\begin{array}{l}\text { BE length } 6 \pm 2 \mathrm{~cm} \\
\text { preoperatively to } 2 \pm 1 \mathrm{~cm} \\
\text { postoperatively: } \\
\text { - Length had } \\
\text { decreased/disappeared } \\
\text { in four patients } \\
\text { - Complete resolution of } \\
\text { BE in two patients } \\
\text { - Improvement in degree } \\
\text { of dysplasia in three } \\
\text { patients }\end{array}$ \\
\hline $\begin{array}{l}\text { Signorini, 2020 } \\
\text { (retrospective) }^{54}\end{array}$ & RYGB & 9 & $\begin{array}{l}\text { Consecutive patients } \\
\text { with RYGB }\end{array}$ & $\begin{array}{l}24 \\
\text { months }\end{array}$ & $\begin{array}{l}\text { SSBE: } 75 \% \\
\text { resolution } \\
\text { LSBE: } 40 \% \\
\text { resolution }\end{array}$ & $\begin{array}{l}\text { Preoperative BE: SSBE } \\
45 \% \text { and LSBE } 55 \% \text { : } \\
\text { - SSBE } 75 \% \text { resolved } \\
\text { - LSBE } 40 \% \text { resolved } \\
\text { - No progression to } \\
\text { dysplasia }\end{array}$ \\
\hline
\end{tabular}

Abbreviations: RYGB, Roux-en-Y gastric bypass; LRRYGB, laparoscopic resectional Roux-en-Y gastric bypass; BE, Barrett's esophagus; SG, sleeve gastrectomy; SSBE, short-segment Barrett's esophagus; LSBE, long-segment Barrett's esophagus; IM, intestinal metaplasia; PPI, proton pump inhibitor.

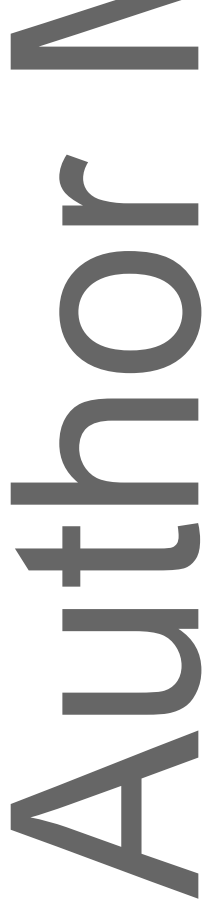




\section{University Library}

\section{- M M N E R VA A gateway to Melbourne's research publications}

Minerva Access is the Institutional Repository of The University of Melbourne

Author/s:

Ooi, GJ;Browning, A;Hii, MW;Read, M

Title:

Perioperative screening, management, and surveillance of Barrett's esophagus in bariatric surgical patients

Date:

2020-08-13

Citation:

Ooi, G. J., Browning, A., Hii, M. W. \& Read, M. (2020). Perioperative screening, management, and surveillance of Barrett's esophagus in bariatric surgical patients. ANNALS OF THE NEW YORK ACADEMY OF SCIENCES, 1481 (1), pp.224-235. https:// doi.org/10.1111/nyas.14441.

Persistent Link:

http://hdl.handle.net/11343/276144 